\title{
Comparative Single Dose Pharmacokinetics and Bioavailability Studies of Saquinavir, Ritonavir and their Optimized Cyclodextrin Complexes after Oral Administration into Rats using LC-MS/MS.
}

\author{
Bharani S Sogai', Vikram B Narayansetty', Ramana Murthy V Kolapalli² \\ 'Department of Pharmaceutics, Krupanidhi College of Pharmacy, Bangalore, Karnataka, INDIA. \\ ${ }^{2}$ Department of Pharmaceutics, Andhra University, Visakhapatnam, Andhra Pradesh, INDIA.
}

\begin{abstract}
Purpose: To compare pharmacokinetics and bioavailability of saquinavir (SOV) and ritonavir (RTV) and their optimized cyclodextrin complexes of anti-retro viral drugs after oral administration into rats. Methods: Rats were fasted overnight and dose equivalent to $10 \mathrm{mg} / \mathrm{kg}$ was administered orally via feeding tubes. Serial blood samples were collected, and plasma concentrations of both drugs and their complexes were determined using liquid chromatography tandem mass spectrometry, LCMS/MS. Results: After oral administration, half-life, apparent volume of distribution, total body clearance and bioavailabilities were calculated for both drugs and their optimized cyclodextrin complexes. The cyclodextrin complexes of both saquinavir $(3860.93 \pm 138.50 \mathrm{ng} . \mathrm{h} / \mathrm{ml})$ and ritonavir $(2300.19 \pm 118.21 \mathrm{ng} . \mathrm{h} / \mathrm{ml})$ had shown higher $\mathrm{AUC}_{0-\infty}$ values compared to pure drugs, saquinavir $(2293.04 \pm 82.13 \mathrm{ng} . \mathrm{h} / \mathrm{ml})$ and ritonavir (1636.07 \pm 162.51 $\mathrm{ng} . \mathrm{h} / \mathrm{ml}$ ). Conclusion: Orally administered cyclodextrin complexes of SQV and RTV had shown higher bioavailabilities and higher peak plasma concentrations compared to SOV and RTV.
\end{abstract}

Key words: Oral, LCMS/MS, Plasma, Bioavailability.

\section{INTRODUCTION}

Human Immunodeficiency virus (HIV) gradually impairs human immune system and leads to acquired immune deficiency syndrome. There are several combinations of drug treatments available to reduce the replication of virus. Among them, protease inhibitors are effective in reducing the infection by binding to protease enzyme and preventing multiplication of virus. Because of the probability of developing viral resistance, side effects and low patient compliance, different protease inhibitors are prescribed in anti-retro viral therapy. ${ }^{1}$ Saquinavir and Ritonavir, extensively prescribed protease inhibitors belong to BCS class II drugs and exhibit low and highly variable oral absorption because of their low aqueous solubility. For increasing their bioavailability, there is a need to enhance solubility and dissolution rate as their oral absorption is dissolution rate limited.

Among various techniques available, complexation with cyclodextrins (CD) gained importance in improving the solubility, dissolution rate, stability, and bioavailability of poorly water-soluble compounds. The solubility is enhanced because of forming water soluble inclusion complexes by encapsulating hydrophobic moiety of the drug which results in changing physicochemical properties and hence enhanced solubility. ${ }^{2-4}$ In the present study, different cyclodextrin complexes were prepared using methods like physical mixture, kneading, solvent evaporation, spray drying and freeze drying.
Submission Date: 23-01-2018; Revision Date: 15-02-2018; Accepted Date: 17-05-2018

DOI: 10.5530/ijper.52.4.68 Correspondence: Bharani S Sogali, Department of Pharmaceutics, Krupanidhi College of Pharmacy, Bangalore 560035, Karnataka, INDIA. Phone: +9199806 47992 E-mail: bssogali@gmail.com

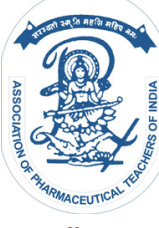

www.ijper.org 
All complexes were evaluated for increase in rate of dissolution and statistical analysis was employed for optimization. Both SQV and RTV showed the highest dissolution by freeze drying method. SQV showed better dissolution with sulfo butyl ether $\beta$ cyclodextrin (SBE7 $\beta C D$ ) prepared using freeze drying method and RTV showed highest dissolution with freeze dried randomly methylated $\beta$ cyclodextrin complex (RM $\beta C D) .{ }^{1}$ The purpose of this study was to investigate the bioavailability of SQV and RTV in complex form with optimized CD derivatives in comparison with the free SQV and RTV through the gastrointestinal absorption. We have applied a recently reported specific and sensitive LCMS/MS assay ${ }^{6}$ to determine pharmacokinetics of cyclodextrin complexes. In the present investigation, plasma concentrations of saquinavir and ritonavir and their optimized cyclodextrin complexes were determined by using LC-MS/MS. ${ }^{7-9}$

\section{MATERIALS AND METHODS Materials}

Saquinavir and Ritonavir were provided by Hetero Chemicals, Hyderabad. Sulfo butyl ether $\beta$ cyclodextrin was kindly gifted by Cydex Pharmaceuticals, USA. Randomly methylated $\beta$ cyclodextrin was provided by Roquette Pharma, Italy. Acetonitrile and other solvents were of HPLC grade and procured from Himedia Labs, Bangalore. All other reagents used were of Analytical grade.

\section{Preparation of inclusion complexes Freeze drying/lyophilisation ${ }^{10,11}$}

The dispersion of drug and optimized cyclodextrin derivatives were prepared with sufficient quantity of water at 1:1 molar ratio and kept for stirring at $200 \mathrm{rpm}$ for $72 \mathrm{~h}$ at neutral $\mathrm{pH}$ in closed vials for complex formation which results in getting a clear solution. The resulting solution was fast frozen at $-20^{\circ} \mathrm{C}$ using liquid nitrogen and dried at $-50^{\circ} \mathrm{C}$ and 0.0070 mbar pressure in a freeze dryer (Model MODUL YOD 230, Thermo Electron Corporation, India) for $48 \mathrm{~h}$. The product was stored in the desiccator for further pharmacokinetic analysis.

\section{Animals}

The pharmacokinetic study protocol was approved by the Institutional Animal Ethics Committee, SreeSiddaganga College of Pharmacy, Tumkur. The animals were obtained from Central Animal House, SreeSiddaganga College of Pharmacy. The study was conducted in male Wistar rats (150-200g) following oral administration of both drugs and their optimized complexes. The animals were housed in cages with proper environmental control with free access to standard diet and water.

\section{Study design}

The animals were divided into four groups, each group containing four animals. Group 1 was given SQV, Group 2 was administered with SQV-SBE7ßCD complex. Group 3 was given RTV and Group 4 was administered with RTV-RM $\beta C D$ complex. After keeping animals for overnight fasting, drug equivalent to $10 \mathrm{mg} / \mathrm{Kg}$ of rat was calculated and both drugs and their complexes were dispersed in $1 \mathrm{ml}$ of sodium carboxy methyl cellulose (sodium CMC) solution $(0.1 \% \mathrm{w} / \mathrm{v})$ and was given orally via feeding tube. ${ }^{12}$

\section{Blood sampling}

Serial blood samples $(1 \mathrm{ml})$ were collected from retro orbital plexus of rats into micro centrifuge tubes containing EDTA coated tubes. Samples were taken at $0,0.5,1,2,4,8,12 \mathrm{~h}$ post-dose. The animals were fed with standard diet after $4^{\text {th }} \mathrm{h}$ sampling. After each withdrawal of blood, equal volume of intra peritoneal saline was replaced. For separation of Plasma, centrifugation $(2000 \mathrm{~g})$ under refrigeration $\left(2-8^{\circ} \mathrm{C}\right)$ for $10 \mathrm{~min}$ was performed and each plasma sample was immediately collected and stored at $-20^{\circ} \mathrm{C}$ until drug analysis.

\section{Chromatographic Conditions}

For detection, Atmospheric pressure ionization (API) 4000 triple quadrupole mass spectrometer detector equipped with turbo ion spray source and operated in the positive mode. Analysis was performed with electrospray ionization using a turbo ion spray ionization source. The turbo ion spray ionization source was operated at $550^{\circ} \mathrm{C}$ with an ionization voltage of $5500 \mathrm{~V}$ with ultrahigh-purity nitrogen as curtain gas 60 PSI, nebulizer gas (40 PSI) and auxiliary gas (40 PSI). Nitrogen was used as collision activated dissociation (CAD) gas and was set at $6 \mathrm{~L} / \mathrm{h}$. Quantification was performed using multiple reaction monitoring (MRM) mode based on the precursor $\mathrm{m} / \mathrm{z}$ and its fragment $\mathrm{m} / \mathrm{z}$ (MRM transition) for each analyte. Analyst 1.5.2 software was used for system operation and data handling. Samples were chromatographed on a Waters BEH C18 (Ethylene bridged Hybrid particles with $1.7 \mu \mathrm{m}$ particle size), $50 \mathrm{x}$ $2.1 \mathrm{~mm}$ (length $\mathrm{x}$ dia) column. The temperature of the column was maintained at $35^{\circ} \mathrm{C}$.

Formic acid buffer $(0.1 \%)$ and acetonitrile in the ratio of $50: 50 \mathrm{v} / \mathrm{v}$ were used as mobile phase. The mobile phase components were filtered before use through a $0.45 \mu \mathrm{m}$ membrane filter and pumped isocratically at a flow rate of $1.0 \mathrm{ml} / \mathrm{min}$. The volume of the sample analyzed was 
$10 \mu$ l. The drug concentrations (analytes) were detected by monitoring the transactions $675.5 \pm 0.5$ amu to 570.5 $\pm 0.5 \mathrm{amu}$ and $721.5 \pm 0.5 \mathrm{amu}$ to $296.30 \pm 0.5 \mathrm{amu}$ with collision energy of 4 and $27 \mathrm{~V}$ for both the drugs and lopinavir which was used as internal standard (IS) respectively. The analytical time for each run was $3 \mathrm{~min}$ in total.

\section{Analytical Method}

The determination of SQV and RTV plasma samples was performed using a previously described LCMS/ MS method. ${ }^{6}$ Lopinavir was chosen as internal standard because it showed similar chromatographic behavior to both SQV, RTV with no interference with both saquinavir and ritonavir by admixture in rat plasma. Parent and daughter ion spectra of $\mathrm{SQ}<\mathrm{RTV}$ and LPV are given in Figure 1. The chromatograms of SQV, RTV were clearly distinguishable and retention times of SQV, RTV and LPV were found to be $0.73,1.96$ and 2.39 min respectively, under specified chromatographic conditions. The assay was validated with a detection limit of $20 \mathrm{ng} / \mathrm{ml}$ for both drugs and a lower limit of quantification and
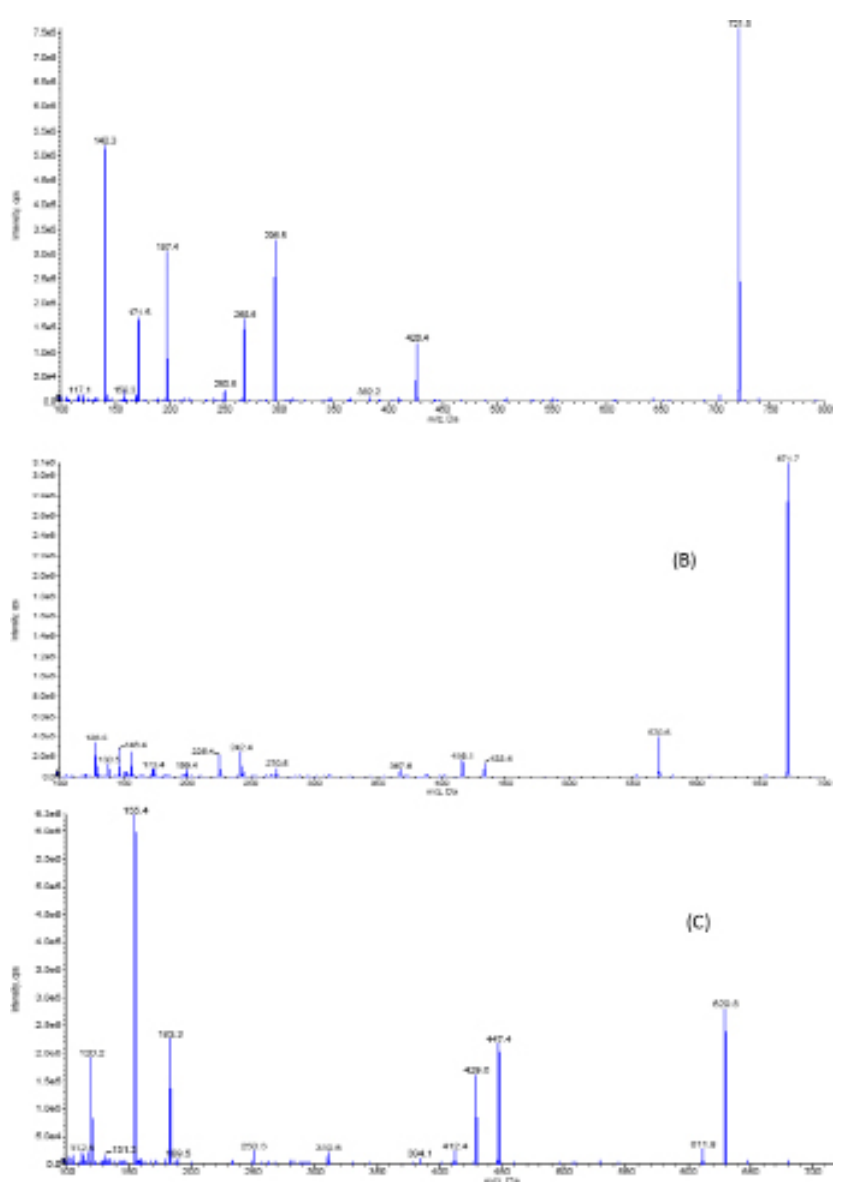

Figure 1: Parent molecule and daughter ion mass spectrum of A) ritonavir B) saquinavir C) lopinavir. upper limit of quantification were found to be 71.7 and $1570 \mathrm{ng} / \mathrm{ml}$ (SQV) and 60.9 and $1650 \mathrm{ng} / \mathrm{ml}$ (RTV). The correlation coefficients ( $\mathrm{r}$ ) of the calibration curves greater than 0.99 for all analytes as determined by linear regression analysis for saquinavir and for ritonavir, with a $1 / x^{2}$ regression, where $x$ is the concentration, over a concentration range of $50-1500 \mathrm{ng} / \mathrm{ml}$ for both the drugs. A representative calibration curve of SQV and RTV for resulted in the linear least squares regression equations, SQV: $y=0.000368 x+-0.0154$, RTV: $y=0.000646 x+4.14 e^{-005}$, where $x$ is the concentration of SQV and RTV $(\mathrm{ng} / \mathrm{mL})$ and $\mathrm{y}$ is the peak area ratio of both SQV and RTV to the IS. Both drugs were found to be stable in rat plasma at least one month at $-20^{\circ} \mathrm{C}$.

\section{Pharmacokinetic analysis}

$20 \mu$ l of internal standard solution was added to aliquots of $100 \mu \mathrm{l}$ of plasma from study samples in $1.5 \mathrm{ml}$ microcentrifuge tubes, and mixed gently. Each tube was added with $400 \mu$ l of acetonitrile and vortexed for $20 \mathrm{sec}$ at high speed. The tube was centrifuged at $12,000 \times \mathrm{g}$ for $5 \mathrm{~min}$ to pellet the precipitated proteins and give a clear supernatant. These clear supernatants were transferred to vials and were placed in the auto sampler tray for injection onto the LC column and $5 \mu \mathrm{l}$ plasma volume was injected into LC-MS/MS system.

\section{Data analysis}

Pharmacokinetic parameters were analyzed using standard, non-compartmental techniques. From the plasma concentration-time curves, maximum plasma drug concentrations (Cmax) and the time to reach these concentrations $\left(\mathrm{T}_{\max }\right)$ were determined.The pharmacokinetic parameters $\mathrm{C}_{\max }, \mathrm{T}_{\max }$, Area Under the Curve (AUC), Apparent terminal elimination rate constant $\left(K_{e}\right)$, Apparent terminal elimination half-life $\left(t_{1 / 2}\right)$, Area under the first moment of plasma concentration-time curve (AUMC), Mean residence time (MRT), Apparent total body clearance, Apparent volume of distribution $\left(\mathrm{V}_{\mathrm{d}} / \mathrm{F}\right)$ of both drugs were estimated form the individual plasma drug concentration-time profile using noncompartmental analysis. ${ }^{13-16}$

\section{Statistical analysis}

The pharmacokinetic parameters of the tested formulations were statistically analysed using unpaired t-test for $\mathrm{C}_{\max }, \mathrm{AUCO}_{-12 \mathrm{~h}}$ and $\mathrm{AUC}_{0-\infty}$ values. ${ }^{17}$ All tests were performed using Graph Pad Prism 5.03 (Graph Pad Software, Inc.CA, USA) software (trial version). The level of significance was set at $\mathrm{p}<0.05$. 
RESULTS AND DISCUSSION

\section{Pharmacokinetic evaluation of SQV-SBE7 $\beta C D$ complex}

LCMS chromatograms of SQV, RTV and LPV in blank plasma is given in Figure 2 and 3.The comparative mean plasma concentration-time profiles of SQV for both treatments are shown in Figure 4.

$\mathrm{C}_{\max }$ and the time to reach $\mathrm{C}_{\max }\left(\mathrm{T}_{\max }\right)$ were read directly from the observed plasma concentration vs. time data. The plasma elimination half-life was estimated from the log-linear regression of the terminal plasma concentrations as a function of time after dosing. The area under the plasma concentration vs. time curve was calculated by using the linear trapezoidal rule over a single hour dosing interval. All the calculated pharmacokinetic parameters such as $\mathrm{C}_{\max }, \mathrm{T}_{\max }, \mathrm{AUC}_{0-12 \mathrm{~h}}, \mathrm{AUC}_{0-\infty}, \mathrm{AUMC}_{0-\infty}$, MRT, $\mathrm{K}_{\mathrm{e}}, \mathrm{t}_{1 / 2}, \mathrm{~V}_{\mathrm{d}} / \mathrm{F}$ and $\mathrm{Cl} / \mathrm{F}$ for each subject following single oral administration of SQV and its complex and mean, s.d., $\% \mathrm{CV}$ values of pharmacokinetic parameters for each subject are given in Table 1 . The $\mathrm{C}_{\max }$ of SQV from SQV and SQV complex with SBE7 $\beta C D$ was found to be $254 \pm 18.81$ and $515.25 \pm 28.65 \mathrm{ng} / \mathrm{ml}$ respectively. The $\mathrm{T}_{\max }$ values were unchanged and found to be $4 \mathrm{~h}$ for
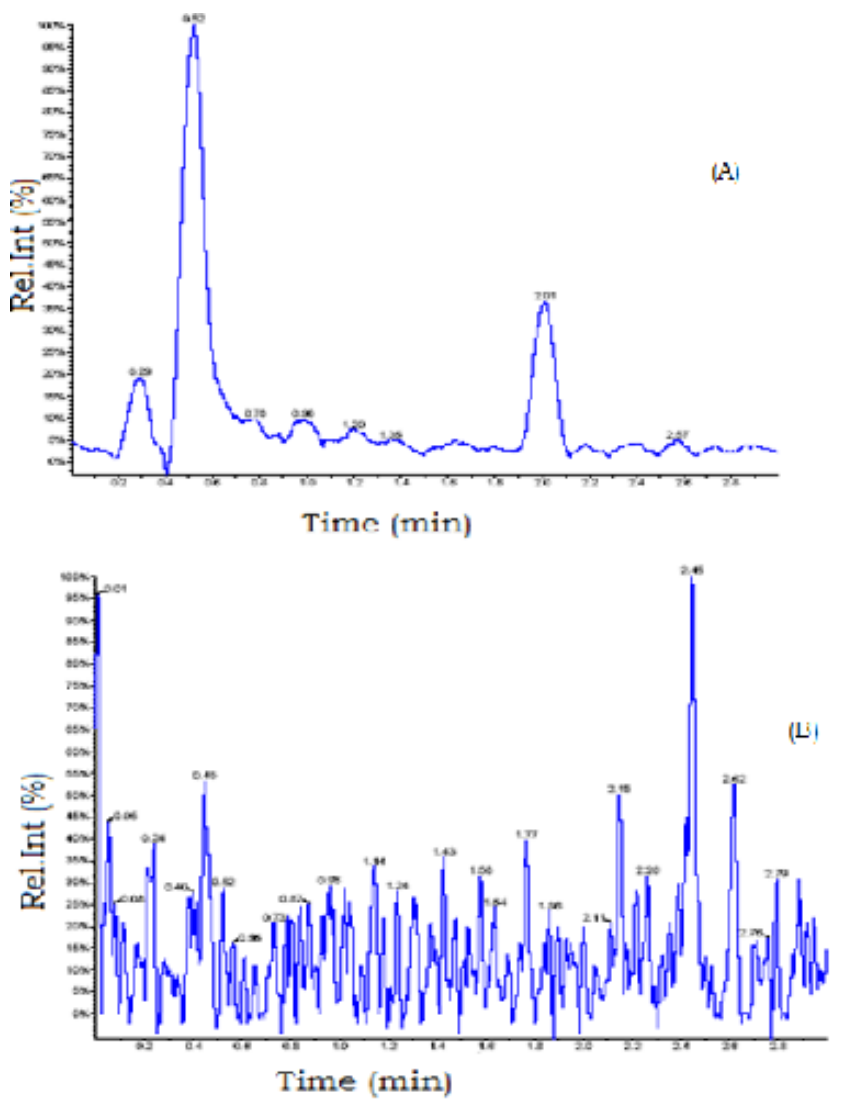

Figure 2: LCMS spectra of A) SQV B) LPV (IS) in blank plasma.
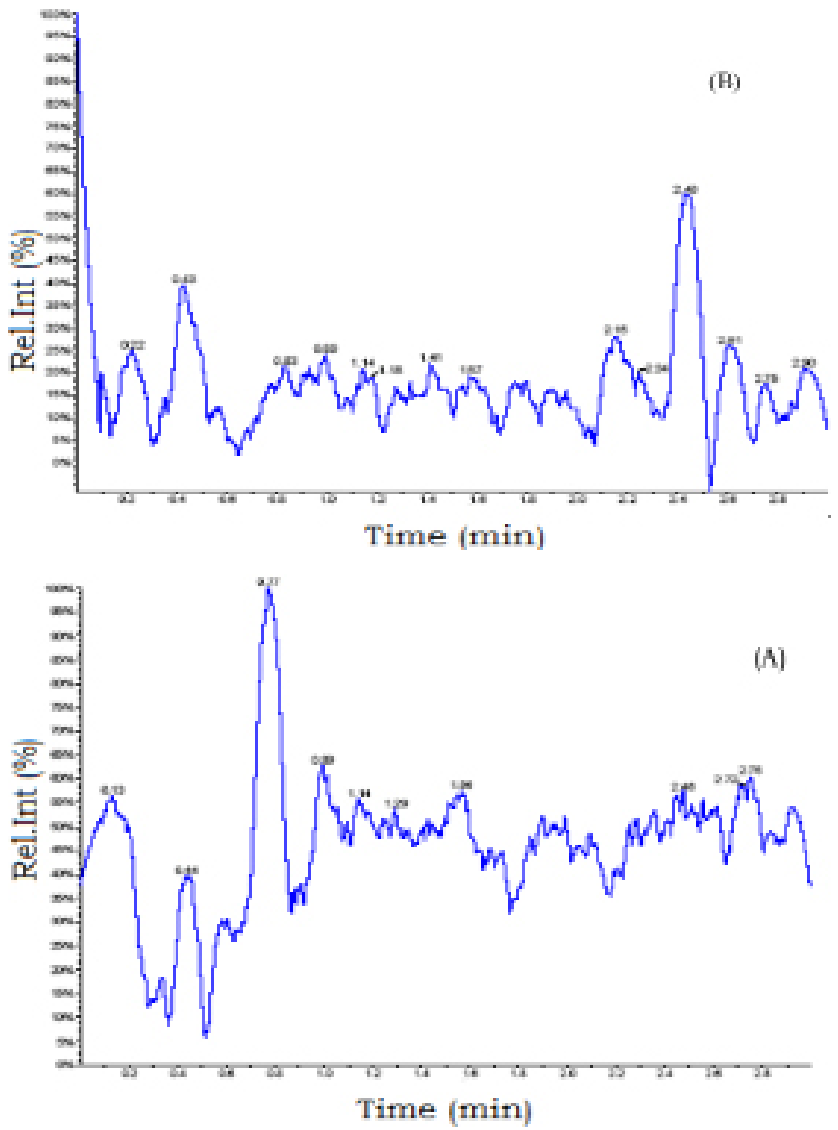

Figure 3: LCMS Spectra of A) RTV and B) LPV (IS) in blank plasma.

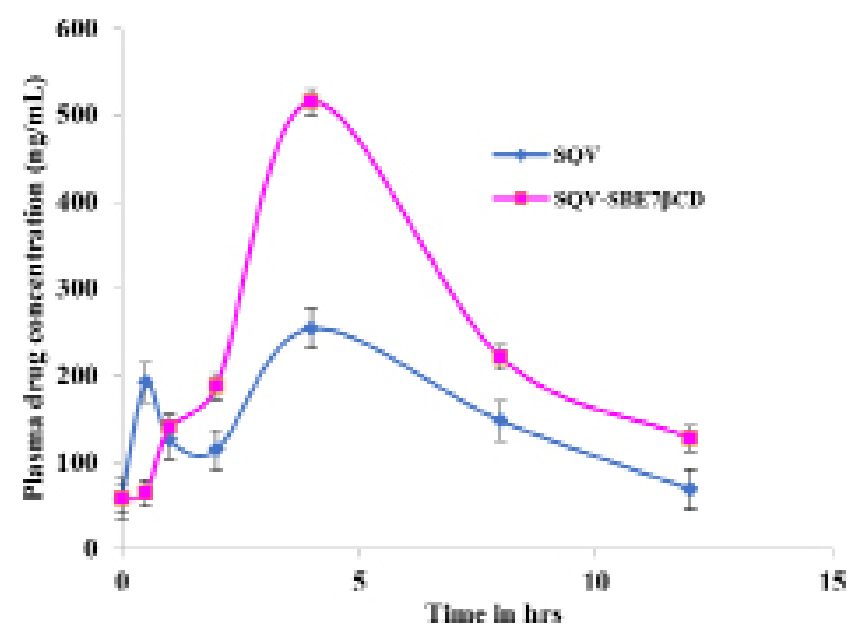

Figure 4: Comparative mean SQV plasma concentration-time profile.

both groups. The elimination rate constant and $t_{1 / 2}$ were found to be in the range of 0.163 to $0.175 \mathrm{~h}^{-1}$ and 3.99 to $4.26 \mathrm{~h}$ respectively for both groups. The obtained $\mathrm{t}_{1 / 2}$ of SQV was found to be in the range of earlier reported values $(3.5-4.5 \mathrm{~h}) .^{18}$

$\mathrm{AUC}_{0-12 \mathrm{~h}}$ and $\mathrm{AUC}_{0-\infty}$ values for $\mathrm{SQV}$ were found to be $1867.5 \pm 42.07$ and $2293.04 \pm 82.13 \mathrm{ng} . \mathrm{h} / \mathrm{ml}$ respectively. For SQV complex, the respective values were found to be $3116.99 \pm 116.46$ and $3860.93 \pm 138.50 \mathrm{ng} . \mathrm{h} / \mathrm{ml}$. 


\begin{tabular}{|c|c|c|c|c|c|}
\hline \multirow[b]{2}{*}{ Parameters } & \multirow[b]{2}{*}{ Units } & \multicolumn{2}{|l|}{ SQV } & \multicolumn{2}{|c|}{ SQV-SBE7 $\beta C D$ complex } \\
\hline & & Mean士 SD $(n=4)$ & $\% \mathrm{CV}$ & Mean \pm SD $(n=4)$ & $\% \mathrm{CV}$ \\
\hline $\mathrm{K}_{\mathrm{e}}$ & $\mathrm{hr}^{-1}$ & $0.163 \pm 0.01$ & 7.83 & $0.175 \pm 0.02$ & 13.71 \\
\hline$t_{1 / 2}$ & $\mathrm{hr}$ & $4.26 \pm 0.32$ & 7.68 & $3.99 \pm 0.50$ & 12.59 \\
\hline $\mathrm{T}_{\max }$ & $\mathrm{hr}$ & $4.00 \pm 0.00$ & -- & $4.00 \pm 0.00$ & -- \\
\hline $\mathrm{C}_{\max }$ & $\mathrm{ng} \cdot \mathrm{hr} / \mathrm{mL}$ & $254.00 \pm 18.81$ & 7.40 & $515.25 \pm 28.65$ & 5.56 \\
\hline $\mathrm{AUC}_{0-12 \mathrm{hr}}$ & ng.hr/mL & $1867.5 \pm 42.07$ & 2.25 & $3116.99 \pm 116.46$ & 3.73 \\
\hline $\mathrm{AUC}_{0-\infty}$ & $\mathrm{ng} \cdot \mathrm{hr} / \mathrm{mL}$ & $2293.04 \pm 82.13$ & 3.58 & $3860.93 \pm 138.50$ & 3.58 \\
\hline $\mathrm{AUMC}_{0-\infty}$ & ng.hr/mL & $21679.30 \pm 1486.90$ & 6.85 & $36970.91 \pm 4044.98$ & 10.94 \\
\hline MRT & $\mathrm{hr}$ & $9.44 \pm 0.38$ & 4.04 & $9.55 \pm 0.75$ & 7.91 \\
\hline$V_{d} / F$ & L & $26.83 \pm 1.69$ & 6.31 & $14.92 \pm 1.56$ & 10.47 \\
\hline $\mathrm{Cl} / \mathrm{F}$ & $\mathrm{L} / \mathrm{hr}$ & $4.36 \pm 0.158$ & 3.62 & $2.59 \pm 0.09$ & 3.58 \\
\hline
\end{tabular}

Two fold increment in $\mathrm{C}_{\max }$ value and 1.66 fold increment in $\mathrm{AUC}_{0-12 \mathrm{~h}}$ were obtained for $\mathrm{SQV}$ complex than SQV alone. The relative percent bioavailability $\left(\mathrm{F}_{\text {ree }}\right)$ of SQV complex was $168 \%$ indicating enhanced oral bioavailability of SQV complex. Plasma concentration-time profile of SQV showed low and double peak phenomenon whereas SQV-SBE77ßCD showed smooth elevation of plasma levels with one $\mathrm{C}_{\max }$ value i.e. single peak. The $\mathrm{V}_{\mathrm{d}} / \mathrm{F}$ and $\mathrm{Cl} / \mathrm{F}$ were found to be $26.83 \pm 1.69 \mathrm{~L}$ and $4.36 \pm 0.15 \mathrm{~L} / \mathrm{h}$ respectively for SQV, $14.92 \pm 1.56 \mathrm{~L}$ and $2.59 \pm 0.09 \mathrm{~L} / \mathrm{h}$ respectively for SQV complex.

The variability in oral pharmacokinetics of SQV could also be explained by its limited solubility. Because the water solubility of SQV is negligible, its dissolution in GIT is dependent on the $\mathrm{pH}$ and the inherent solubilization capacity of the intestine. In rats receiving SQV suspension, a small variation of these factors could lead to a significant difference in dissolution properties and subsequently in the plasma drug concentration. However, in rats receiving SQV-SBE7 $\beta C D$, as SBE7 $\beta C D$ could solubilize SQV, the impact of such factors became nondeterminative and thus, the oral kinetics in rats receiving SQV-SBE7BCD showed less variability than that in rats receiving $\mathrm{SQV}$ suspension. It was noticed that there was a primary peak at $0.5 \mathrm{~h}$ and a secondary peak at about $4 \mathrm{~h}\left(\mathrm{~T}_{\max }\right)$ after dosing in the concentration vs. time graph for rats given the SQV suspension where as such a phenomenon was not observed for the rats receiving SQV-SBE7ßCD. Several possible mechanisms have been proposed to explain double peak phenomenon of orally administered protease inhibitors such as enterohepatic recycling, regional distribution differences of active absorption/efflux proteins in the gut, and variable gastric emptying. Earlier literature on SQV also reported similar type of double peak absorption phenomenon as observed in the present investigation. ${ }^{12,19,20}$

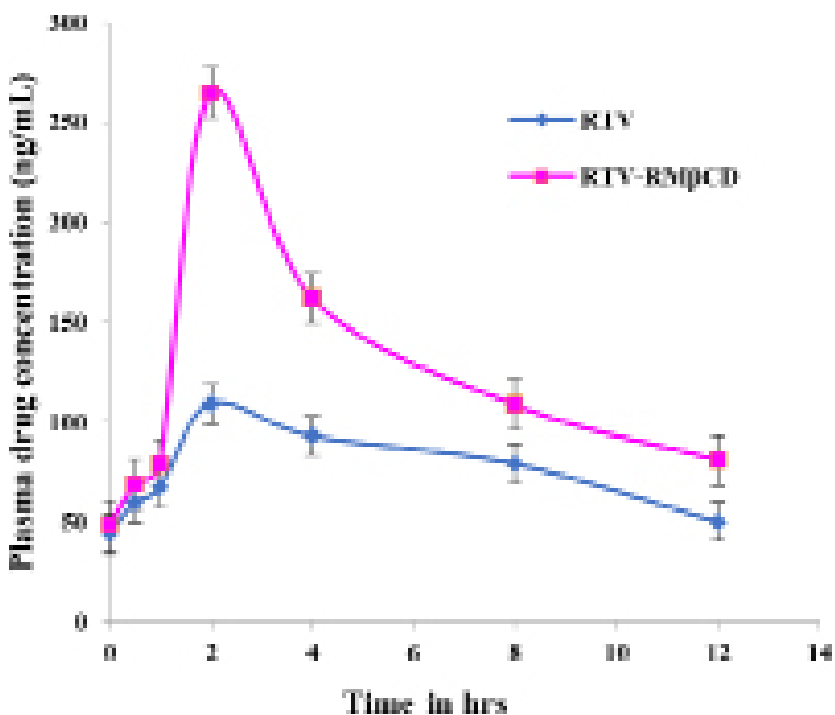

Figure 5: Comparative mean RTV plasma concentration-time profile.

\section{Pharmacokinetic evaluation of RTV-RM $\beta$ CD complex}

The comparative mean plasma concentration-time profiles of RTV for both treatments are shown in Figure 5. All the calculated pharmacokinetic parameters such as $\mathrm{C}_{\max }, \mathrm{T}_{\max }, \mathrm{AUC}_{0-12 \mathrm{~h}}, \mathrm{AUC}_{0-\infty}, \mathrm{AUMC}_{0-\infty}, \mathrm{MRT}, \mathrm{K}_{\mathrm{e}}, \mathrm{t}_{1 / 2}$, $\mathrm{V}_{\mathrm{d}} / \mathrm{F}$ and $\mathrm{Cl} / \mathrm{F}$ for each subject following single oral administration of RTV and its CD complex and mean, s.d., \% CV values of pharmacokinetic parameters for each subject are given in Table 2. The peak plasma concentration $\left(\mathrm{C}_{\max }\right.$ RTV in the pure drug and its complex were $109.17 \pm 9.6$ and $264.74 \pm 16.52 \mathrm{ng} / \mathrm{ml}$, while $\mathrm{AUC}_{0-12 \mathrm{~h}}$ and $\mathrm{AUC}_{0-\infty}$ were found to be $951.20 \pm 28.54$, 1636.07 $\pm 162.51 \quad$ ng.h/ml, $1585.16 \pm 56.22$ and $2300.19 \pm 118.21$ ng.h/ml respectively. These values indicated maximum plasma concentration and area under the curve were achieved by RTV complex formulation. $\mathrm{C}_{\max }$ value was 2.4 times and $\mathrm{AUC}_{0-12 \mathrm{~h}}$ was 1.66 


\begin{tabular}{|c|c|c|c|c|c|}
\hline \multirow[b]{2}{*}{ Parameters } & \multirow[b]{2}{*}{ Units } & \multicolumn{2}{|l|}{ RTV } & \multicolumn{2}{|c|}{ RTV-RM $\beta C D$ complex } \\
\hline & & Mean \pm s.d. $(n=4)$ & $\% \mathrm{CV}$ & Mean士 s.d. $(n=4)$ & $\% \mathrm{CV}$ \\
\hline $\mathrm{K}_{\mathrm{e}}$ & $\mathrm{hr}^{-1}$ & $0.075 \pm 0.011$ & 15.86 & $0.115 \pm 0.0144$ & 12.5 \\
\hline$t_{1 / 2}$ & $\mathrm{hr}$ & $9.37 \pm 1.59$ & 17.00 & $6.07 \pm 0.69$ & 11.43 \\
\hline$T_{\max }$ & $\mathrm{hr}$ & $2.00 \pm 0.0$ & -- & $2.00 \pm 0.00$ & -- \\
\hline $\mathrm{C}_{\max }$ & $\mathrm{ng} \cdot \mathrm{hr} / \mathrm{mL}$ & $109.17 \pm 9.60$ & 8.80 & $264.75 \pm 16.52$ & 6.23 \\
\hline$A \cup C_{0-12 h r}$ & $\mathrm{ng} \cdot \mathrm{hr} / \mathrm{mL}$ & $951.20 \pm 28.54$ & 3.00 & $1585.16 \pm 56.22$ & 3.54 \\
\hline$A \cup C_{0-\infty}$ & ng.hr/mL & $1636.07 \pm 162.51$ & 9.93 & $2300.19 \pm 118.20$ & 5.13 \\
\hline $\mathrm{AUMC}_{0-\infty}$ & $\mathrm{ng} \cdot \mathrm{hr} / \mathrm{mL}$ & $25466.92 \pm 6451.36$ & 25.33 & $26866.09 \pm 3505.39$ & 13.04 \\
\hline MRT & $\mathrm{hr}$ & $15.40 \pm 2.25$ & 14.61 & $11.64 \pm 0.97$ & 8.38 \\
\hline $\mathrm{V}_{\mathrm{d}} / \mathrm{F}$ & L & $82.35 \pm 6.45$ & 7.83 & $38.06 \pm 3.10$ & 8.15 \\
\hline $\mathrm{Cl} / \mathrm{F}$ & $\mathrm{L} / \mathrm{hr}$ & $6.15 \pm 0.56$ & 9.16 & $4.35 \pm 0.22$ & 5.09 \\
\hline
\end{tabular}

\begin{tabular}{|c|c|c|c|c|}
\hline Drug & Parameter & Units & $\begin{array}{c}\text { Calculated } \\
\text { t value }\end{array}$ & $\begin{array}{c}\text { P value } \\
\text { (two tailed) }\end{array}$ \\
\hline \multirow{3}{*}{ SQV } & $\mathrm{C}_{\max }$ & $\mathrm{ng} / \mathrm{mL}$ & $15.24^{*}$ & $<0.0001$ \\
\hline & $\mathrm{AUC}_{0-12 \mathrm{hr}}$ & $\mathrm{ng} \cdot \mathrm{hr} / \mathrm{mL}$ & $34.37^{*}$ & $<0.0001$ \\
\hline & $\mathrm{AUC}_{0-\infty}$ & ng.hr/mL & $19.47^{*}$ & $<0.0001$ \\
\hline \multirow{3}{*}{ RTV } & $\mathrm{C}_{\max }$ & $\mathrm{ng} / \mathrm{mL}$ & $16.28^{*}$ & $<0.0001$ \\
\hline & $A \cup C_{0-12 h r}$ & ng.hr/mL & $20.11^{*}$ & $<0.0001$ \\
\hline & $\mathrm{AUC}_{0-\infty}$ & ng.hr/mL & $6.609^{*}$ & $<0.0006$ \\
\hline
\end{tabular}

*significant difference.

times higher for RTV complex than RTV. The relative percent bioavailability $\left(\mathrm{F}_{\text {rel }}\right)$ of RTV complex observed was $140.58 \%$ indicated enhanced oral bioavailability of RTV complex. Pure RTV also exhibited slightly variable bioavailability, which is commonly observed with protease inhibitors. ${ }^{21}$ However, with RTV-RM $\beta C D$ complex, such phenomenon was not observed.

The $T_{\max }$ values were unchanged and found to be $2 \mathrm{~h}$ for both groups. The elimination rate constant was found to be in the range of 0.011 to $0.144 \mathrm{~h}^{-1}$ and $\mathrm{t}_{1 / 2}$ for RTV was found to be $9.37 \pm 1.59 \mathrm{~h}$ and for RTV complex it was $6.07 \pm 0.69 \mathrm{~h}$ respectively for RTV complex and is nearer to the reported values $(6.07-7.35 \mathrm{~h}){ }^{21}$

For pure drug, the $\mathrm{V}_{\mathrm{d}} / \mathrm{F}$ and $\mathrm{Cl} / \mathrm{F}$ were found to be $82.35 \pm 6.45 \mathrm{~L}$ and $6.15 \pm 0.56 \mathrm{~L} / \mathrm{h}$ respectively and for its complex, $38.06 \pm 3.1 \mathrm{~L}$ and $4.35 \pm 0.22 \mathrm{~L} / \mathrm{h}$ respectively.

\section{Statistical analysis}

To test the significant difference if any between complexes and pure drug, pharmacokinetic parameters $\mathrm{C}_{\max }$, $\mathrm{AUC}_{0-12 \mathrm{~h}}$ and $\mathrm{AUC}_{0-\infty}$ were subjected to statistical analysis (Table 3). The results of statistical analysis showed significant difference as the $\mathrm{p}$ value is $<0.05$. The $\mathrm{C}_{\max }$ and AUC values of the experimental formulation were significantly higher compared to the pure drug indicating the higher bioavailability of the experimental formulation of SQV prepared with SBE7 $\beta C D$ and RTV prepared with $\mathrm{RM} \beta \mathrm{CD}$. Thus, the results of the present study clearly indicated the applicability of cyclodextrin complexation in the improvement of oral bioavailability of SQV and RTV compared to pure drugs alone.

\section{CONCLUSION}

Pharmacokinetic studies were conducted in healthy male Wistar rats showed marked increase in the AUC of saquinavir and ritonavir when both the drugs were administered orally in combination with cyclodextrins. Significant enhancement in bioavailability of both drugs was observed with optimized CD complexes compared to pure drugs. The pharmacokinetic parameters like $t_{1 / 2}, T_{\max }$ were in the range of the reported values. The absorption profile of SQV from oral SQV suspension was highly irregular and variable due to its poor solubility. This variation was not seen with SQV-SBE7 $\beta C D$ complex due to improvement in solubility.

\section{ACKNOWLEDGEMENT}

Authors are thankful to Sree Siddhaganga College of Pharmacy for providing facilities for the study and Dr. Akash for performing LC-MS/MS study.

\section{CONFLICT OF INTEREST}

Authors have none to declare.

\section{REFERENCES}

1. Sogali BS, Sushant MS, Ramana MKV. Comparative evaluation of cyclodextrins in improving the dissolution of ritonavir. Int $\mathrm{J}$ Pharmacy. 2016;6(2):159-76. 
2. Shen YL, Yang SH, Wu LM, Ma XY. Study on structure and characterization of inclusion complex of gossypol/beta cyclodextrin. Spectrochimica Acta Part A. 2005;61(6):1025-28.

3. Gazpio C, Sánchez M, Zubiri IX, Vélaz I, Ohárriz CM, Martin C, et al. HPLC and solubility study of the interaction between pindolol and cyclodextrins. J Pharm Biomed Anal. 2005;37(3):487-92.

4. Zhang M, Li J, Zhang L, Chao J. Preparation and spectral investigation of inclusion complex of caffeic acid with hydroxypropyl- $\beta$-cyclodextrin. Spectrochimica Acta Part A. 2009;71(5):1891-5.

5. Loftsson T, Brewster ME, Derendorf H, Bodor N. 2-Hydroxypropyl- $\beta$ cyclodextrin: Properties and usage in pharmaceutical formulations. Pharm Ztg Wiss. 1991;4(1-4):5-10.

6. Chi J, Jayewardene AL, Stone JA, Motoya AT, Aweeka FT. Simultaneous determination of five HIV protease inhibitors nelfinavir, indinavir, ritonavir, saquinavir and amprenavir in human plasma by LCMS. J Pharm Biomed Anal. 2002;30(3):675-84.

7. Volosov A, Alexander C, Ting L, Soldin SJ. Simple rapid method for quantification of antiretrovirals by liquid chromatography-tandem massspectrometry. Clin Biochem. 2002;35(2):99-103.

8. Dickinson L, Robinson L, Tija J, Khoo S, Back D. Simulataneous determination of HIV protease inhibitors amprenavir, atazanavir, indinavir, lopinavir, nelfinavir, ritonavir and saquinavir in human plasma by high-performance liquid chromatography-tandem mass spectrometry. J Chromatogr B. 2005;829(1-2):82-90.

9. Rouzes A, Berthoin K, Xuereb F, Djabarouti S, Pellegrin I, Pellegrin JL, et al. Simulataneous determination of antiretroviral agents: Amprenavir, lopinavir, ritonavir, saquinavir and efavirenz in human peripheral blood mononuclear cells by high-performance liquid chromatography-mass spectrometry. J Chromatogr B. 2004;813(1-2):209-16.

10. Hirayama F, Uekama K. Methods of investigating and preparing inclusion compounds. In: Duchene D, editor. Cyclodextrins and theirindustrial uses. Paris: Editions de Sante. 1987:131-72.

\section{PICTORIAL ABSTRACT}
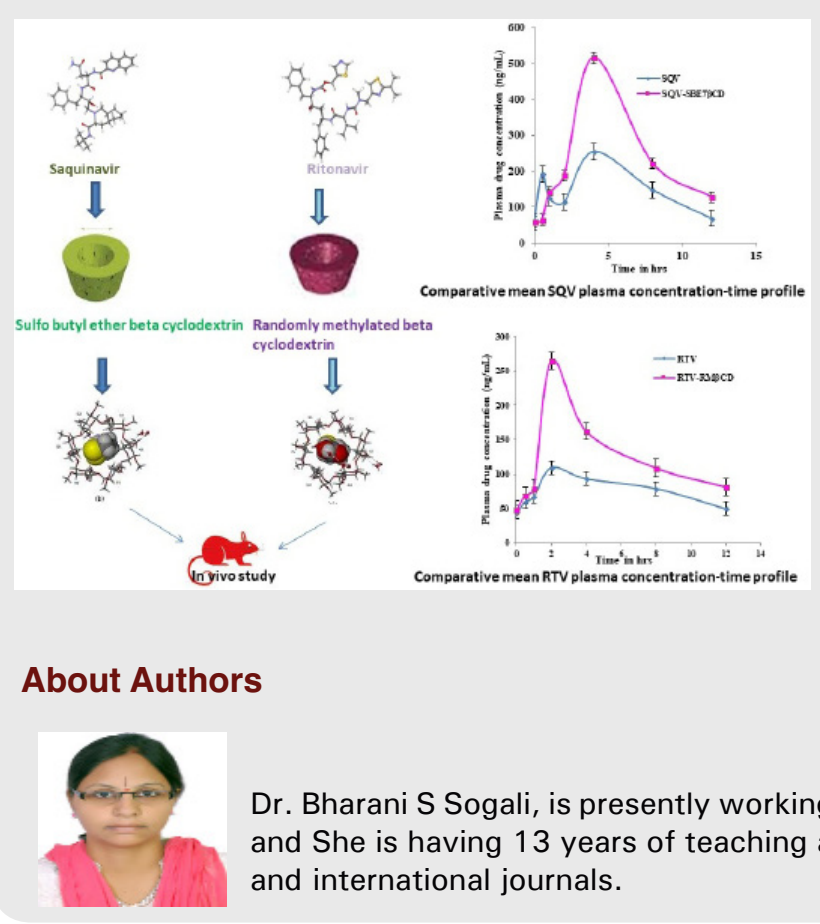
and international journals.
11. Hegdes AR. Industrial applications of cyclodextrins. Chem Rev. 1998;98(5):2035-44.

12. Shilpi S, Mushir A, Sanjula B, Alka A, Anil, Javed A. Solid dispersion as an approach for bioavailability enhancement of poorly water soluble drug, ritonavir. AAPS Pharm Sci Tech. 2010;11(2):518-27.

13. Der VanLinde. Statistical comment on a new method for noncompartmental pharmacokinetic analysis. Biometr J. 1988;30(1):123-27.

14. Gibaldi M, Perrier D. Pharmacokinetics. $2^{\text {nd }}$ ed. New York: Informa Healthcare. 2007.

15. Foster DM. Non compartmental versus compartmental approaches to pharmacokinetic analysis, In: Atkinson AJ, Abernethy DR, Daniel CE, Dedrick RL, Markey SP (eds.), Principles of clinical pharmacology. Massachusetts: Academic Press. 2007:89-105.

16. Muir KT, Gomeni RO. Non-compartmental analysis. In: Bonate P, Howard $\mathrm{D}$ (eds.), Pharmacokinetics in drug development: Clinical study design and analysis. Arlington, VA: AAPS Press. 2004:235-65.

17. Bolton S, Bon C. Nonparametric methods, Pharmaceutical statistics: Practical and clinical applications. $5^{\text {th }}$ ed. New York: Informa Healthcare. 2010:390-424.

18. Von Hentig N, Nisius G, Lennemann T, Khaykin P, Stephan C, Babacan E, et al, Pharmacokinetics, safety and efficacy of SQV/ritonavir 1000/100 mg twice daily as HIV type-1 therapy and transmission prophylaxis in pregnancy. Antivir Ther. 2008;13(8):1039-46.

19. Werner W, Annika B, Thomas G, Michael Z, Christiane M, Vera H, et al. The talinolol double- peak phenomenon is likely caused by presystemic processing after uptake from gut lumen. Pharm Res. 2005;22(5):728-35.

20. Pathak SM, Musmade P, Dengle S, Karthik A, Bhat K, Udupa N. Enhanced oral absorption of saquinavir with methyl-beta-cyclodextrin preparation and in vitro and in vivo evaluation. Eur J Pharm Sci. 2010;41(3-4):440-51.

21. Boffito $M$, Jackson $A$, Amara A, Back $D$, Khoo $S$, Higgs $S$, et al. Pharmacokinetics of darunavir/ritonavir and atazanavir/ritonavir once daily over $72 \mathrm{~h}$ following drug cessation. Antimicrob Agents Chemother. 2011;55(9):4218-23.

\section{SUMMARY}

- A comparative study was performed on pharmacokinetics and bioavailability of saquinavir (SQV) and ritonavir (RTV) and their optimized cyclodextrin complexes of anti-retro viral drugs after oral administration into rats. Plasma concentrations of both drugs and their complexes were determined using liquid chromatography tandem mass spectrometry, LCMS/MS. The cyclodextrin complexes of both saquinavir $(3860.93 \pm 138.50$ $\mathrm{ng} . \mathrm{hr} / \mathrm{ml})$ and ritonavir (2300.19 $\pm 118.21 \mathrm{ng} . \mathrm{hr} /$ $\mathrm{ml}$ ) had shown higher $\mathrm{AUC}_{0-\infty}$ values compared to pure drugs, saquinavir $(2293.04 \pm 82.13 \mathrm{ng} . \mathrm{hr} / \mathrm{ml})$ and ritonavir (1636.07 $\pm 162.51 \mathrm{ng} . \mathrm{hr} / \mathrm{ml}$ ). Higher bioavailability and higher peak plasma concentrations were obtained with cyclodextrin complexes of both SQV and RTV compared to SQV and RTV alone.

Dr. Bharani S Sogali, is presently working as Professor in Krupanidhi College of Pharmacy, Bengaluru and She is having 13 years of teaching and research experience and having publications in national

Cite this article: Sogali BS, Vikram BN, Murthy RKV. Comparative Single Dose Pharmacokinetics and Bioavailability Studies of Saquinavir, Ritonavir and their Optimized Cyclodextrin Complexes after Oral Administration into Rats using LC-MS/MS. Indian J of Pharmaceutical Education and Research. 2018;52(4):587-93. 